International Journal of Health Sciences
Available online at www.sciencescholar.us
Vol. 6 No. 1, April 2022, pages: $92-102$
e-ISSN: 2550-696X, p-ISSN: $2550-6978$
https://doi.org/10.53730/ijhs.v6n1.3311

\title{
Management of HEIs during Pandemic
}

\author{
(1) corssiank \\ Lyubov Kanishevska a, Valentyna Shakhrai b, Svitlana Aleikseieiva c, Oksana Poyasyk ${ }^{\text {d, }}$ \\ Svitlana Tolochko ${ }^{\mathrm{A}}$
}

Manuscript submitted: 16 August 2021, Manuscript revised: 9 November 2021, Accepted for publication: 29 December 2021

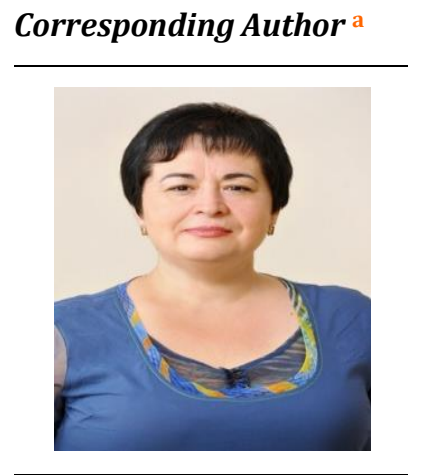

Keywords

blended learning;

distance learning;

health camps;

health courses;

higher education;

medical services;

mental health;

\begin{abstract}
This article aims to assess the changes in the HEIs management system elements during the pandemic. The methodology was built on the analysis of management cases of Kyiv National University named after Taras Shevchenko and National University "Lviv Polytechnic". The internal documentation of HEIs management: strategies and development plans, internal documentation of quality management system implementation defining the main challenges of HEIs management were also used for case analysis. Results. It was determined that the pandemic generated significant structural changes in the system of HEIs management caused by changes in students' needs, development, and spread of innovative learning technologies, reduction in the number of international students, closing, merging, and restructuring of universities due to funding cuts. The pandemic has put forward challenges to the core business of higher education in supporting students through a wide range of curricula. These challenges make it much more difficult to implement interactive, personcentered traditional classroom instruction based on years of university experience. To adapt to a long-term pandemic, HEIs require flexible educational methods that will continuously adapt to different stages. COVID-19 led to the activation of long-term pedagogical trends, created a natural experiment to test and evaluate numerous innovations.
\end{abstract}

International Journal of Health Sciences (C) 2022.

This is an open access article under the CC BY-NC-ND license (https://creativecommons.org/licenses/by-nc-nd/4.0/).

\section{Contents}

Abstract

1 Introduction.

2 Materials and Methods.

93

a Institute of Problems on Education of the NAES of Ukraine, Kyiv, Ukraine

${ }^{b}$ Institute of Problems on Education of the NAES of Ukraine, Kyiv, Ukraine

c Institute of Pedagogy, Kyiv, Ukraine

${ }^{d}$ Vasyl Stefanyk Precarpathian National University, Ivano-Frankivsk, Ukraine

${ }^{\mathrm{e}}$ National Academy of Educational Sciences of Ukraine, Kyiv, Ukraine 


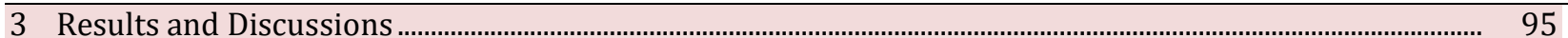

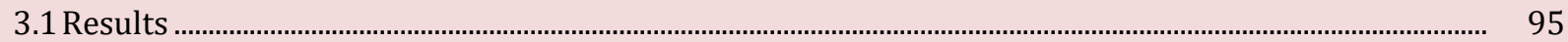

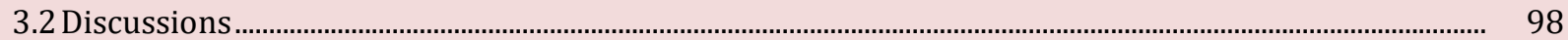

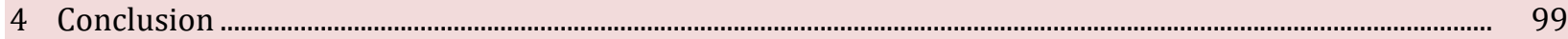

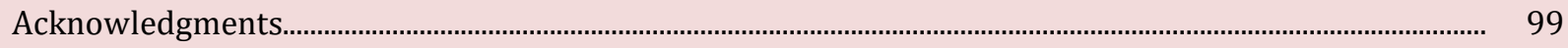

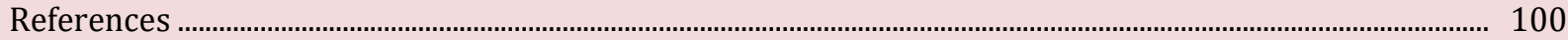

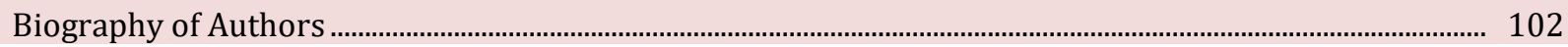

\section{Introduction}

The spread of the COVID-19 pandemic has been an extraordinary challenge for society and the higher education system, changing the paradigm of blended learning, transforming the models of higher education institutions (HEIs) due to the need for instant digitalization (Kaur, 2013; Garrison \& Kanuka, 2004). During the pandemic, higher education institutions are undergoing a radical transformation, driven by the need to digitize education and learning processes in record time. At the same time, the teaching staff is not always fully prepared for the entire transition to online education through the lack of technological capabilities for online teaching. In a crisis emergency, the Learning Management System (LMS) is a vital resource for virtually all higher education institutions and the driving force behind online learning (Arshad et al., 2020).

The pandemic time is characterized by all sorts of problems in the transition to entirely distance learning, despite the introduction of blended learning models in higher education in different countries over the past twenty years. Among the main problems of this period, there are:

- The lack of development of digital infrastructure;

- Insufficient level of the technological expertise of teachers, which affects the quality of learning; lack of clear information from HEIs leadership about the organization of the learning process during the pandemic period, which led to pressure on educators to develop distance learning courses;

- The complexity of the educational process for different participants, reducing the motivation of students during homeschooling;

- The rapid development of digital learning content and adaptation to new learning environments. (Ramírez-Hurtado et al., 2021; Cicha et al., 2021).

The network problems and the lack of educators' technology training were the main problems in the HEIs' transition to virtual classes (Arora \& Srinivasan, 2020). During the pandemic, the role of online learning has been re-thought due to the decreasing level of interest in online education, lack of practical experience, especially in teaching in medical specialties. Among the challenges of distance education: is the effectiveness of virtual classes, low student attendance, lack of interaction, and face-to-face contact due to connectivity issues.

The largest and most developed universities have adapted most effectively to the changes due to their technological advantages and financial resources. Only HEIs who have resources can effectively transform classical education into online learning through expansion and creating a virtual learning environment (Mishra et al., 2020). However, the literature also notes that the pandemic caused by COVID-19 has forced universities to switch from face-to-face to online learning. The transition process has been planned and rapidly implemented with instant course development (Ramírez-Hurtado et al., 2021). The article aimed to assess changes in the elements of the HEIs management system under pandemic conditions.

\section{Literature review}

The scientific literature identifies three main levels of HEIs in higher education quality management: process, organizational, and quality management principles level (TQM) (Manatos et al., 2017). The TQM practices are implemented based on a comprehensive systematic approach and, accordingly, developed strategic plans for the HEIs development (Manatos et al., 2017). Scientists discuss quality criteria for higher education in the

Kanishevska, L., Shakhrai, V., Aleikseieiva, S., Poyasyk, O., \& Tolochko, S. (2022). Management of HEIs during pandemic. International Journal of Health Sciences, 6(1), 92-102.

https://doi.org/10.53730/ijhs.v6n1.3311 
following areas: teaching and learning, educational services, research, and the effectiveness of different approaches at the institutional level (Stensaker et al., 2011). The implementation of TQM practices is associated with the need to reduce the level of educational services fragmentation and to establish cooperation between universities to share knowledge, experience, research, and developments. The integration of TQM principles and elements necessitated the implementation of developed HEIs strategies to meet the demands of a highly competitive market environment. As a result of strategic development plans' implementation, arise and develop international HEIs' quality ratings on various components, including management. An example is the development of international and domestic tools for HEIs' classifying and rating, adopting a wide range of efficiency and performance indicators (Van Vught \& Westerheijden, 2010).

The university management context is becoming increasingly integrated, leading to the centralization of power in a small number of decision-making bodies that handle higher education (HEIs) (Melo et al., 2010). In practice, universities are following TQM implementation trends to better integrate different management practices into a global quality management system (Manatos et al., 2017; Widana et al., 2021).

Bao (2020), proposes six specific learning strategies to generalize the online teaching experience in such an environment based on a study of HEIs in China. The basic principles in managing HEI's learning during a crisis are:

- High consistency between student learning and online instructional design;

- Effective delivery of distance instructions and information;

- Adequate support for teaching assistants and faculty to students;

- Quality engagement to breadth improvement and student learning depth;

- An emergency plan to deal with incidents of education online platforms.

HEIs are lacking readiness and action plans for such crises in practice, which is one of the main problems of crisis management Mishra et al. (2020). Analyze the solution of online teaching and learning foundations in education under the COVID-19 pandemic, the effectiveness of available resources of educational institutions in the context of transforming traditional education to online education through virtual classes and other distance teaching methods. In the context of the pandemic, HEIs management focused on organizing training, online sessions, and professional development training programs for teachers to better use technology in the educational process (online tools, techniques, processes, and learning platforms). Toquero (2020), provides the following recommendations to universities to ensure the effectiveness of higher education and training, based on a study of the Philippines HEIs' experiences during the pandemic:

- Integrate Environment and Health Courses in the Curriculum;

- Strengthen Environmental Policies and Hygiene Practices;

- Incorporate an Online Mental Health and Medical Services;

- Migrate Courses, Align Curriculum Competencies, and Scale-up Teachers' Training for Online Learning Instruction;

- Strengthen Research Efforts, Data Monitoring, and Evidence-Based Practices.

Paudel (2021), based on a study of Nepal's online education experience, argues for the importance of time management skills, technology readiness, and computer literacy as essential components of learning management during a pandemic. Paudel (2021), suggests a clear policy for ICT integration and appropriate courses designed with technological readiness in mind for HEIs. Ali (2020), argues for society's need for flexible and sustainable education systems, notes the importance of resources in integrated ICT training and staff readiness, confidence, student accessibility, and motivation. The results of Shahzad et al. (2021), prove the importance of the given information quality and the online learning system quality on the effectiveness of e-learning portals in Malaysia. Blankenberger \& Williams (2020), conclude that institutional integrity and accountability, the recognizing the important role of higher education in social justice will be crucial aspects of the recovery of higher education institutions in the COVID era. Arshad et al. (2020), note the dominant role in making HEIs effective during the pandemic through quality online information, appropriate support given to students by teaching assistants and faculty, and contingency strategies for dealing with unforeseen problems in the online education system. Antonopoulou et al. (2021), identify the important role of transformational 
leadership in ensuring the highest level of efficiency and employee satisfaction of HEIs during a pandemic. Garcia-Morales et al. (2021), note that the university system must strive to overcome the negative effects of pandemic spread and impact on the educational field to be competitive and provide high-quality education in dramatic digital changes, and technological innovation.

Thus, the scientific literature identifies three main levels of HEIs: process, organizational, and total quality management (TQM) principles, determined by the requirements of the external environment affecting the transformation of the education management system (Jouault et al., 2008; Attamimi et al., 2020). The literature also examines the experience of different countries in the most effective elements of HEIs management.

\section{Materials and Methods}

This study used a case analysis method to systematize information on the HEIs management systems transformation under pandemic conditions along the following lines:

- Innovative solutions and management tools;

- Problems in the management of the organization of the educational process, in particular, the communication processes of teachers and students;

- The benefits of transformational change in distance education management;

- Management system at different levels, organizational, process, the level of TQM principles' implementation.

The most effective management systems, according to HEIs ratings of Ukraine, were chosen for analysis: Kyiv National University named after Taras Shevchenko, and National University "Lviv Polytechnic". Internal documentation of HEIs: strategies and development plans, internal documentation of quality management system implementation defining the main challenges of HEIs management were also used for the case analysis.

\section{Results and Discussions}

\subsection{Results}

Since 2020, the COVID-19 pandemic has been a new global challenge to educational development: UNESCO estimates that more than 1.5 billion students in 165 countries have been unable to attend classes (UNESCO, 2021). It represents approximately $90 \%$ of the world's total enrollment. The pandemic has forced the global academic community to consider the new realities of the functioning of educational institutions and to turn to new methods of learning, including distance and online learning. In addition, the economic downturn, caused by the pandemic, affected the HEIs system, in particular, causing: reduced opportunities for HEIs graduates; reduced demand for educational services due to the insolvency of certain segments of the population; changes in student behavior concerning forms of study and preferences for certain programs. The measures taken to minimize the spread of the disease were certainly justified and allowed educational applicants to minimize their risk of contracting COVID-19 (Lytvyn et al., 2021). At the same time, quarantine restrictions posed new challenges to higher education institutions and educational administrations at both the local and national levels. The massive closure of HEIs demonstrated that the educational community is not sufficiently prepared for today's distance education challenges.

The main problems and challenges, which educators and administrators are facing: the effective organization of the distance learning process, adapting educational policy to the present requirements, increasing the financial support of HEIs, the modernization of their material and technical base (Moore et al., 2011; Markova et al., 2017). It is noteworthy that the UNESCO report and the statement of the Bureau of Education say that the disrupted educational process for education applicants could lead to a significant

Kanishevska, L., Shakhrai, V., Aleikseieiva, S., Poyasyk, O., \& Tolochko, S. (2022). Management of HEIs during pandemic. International Journal of Health Sciences, 6(1), 92-102. https://doi.org/10.53730/ijhs.v6n1.3311 
reduction in the level of education of the population (UNESCO, 2021). The UN, for its part, even proposes a new term "generational catastrophe" related to the lack of a normal educational process (United Nations).

The pandemic requires HEIs in Ukraine to develop and implement innovative solutions in a fairly short time, to ensure the implementation of online learning through the use of a variety of web servers, Internet platforms, messengers, information resources, and social networks. Not all HEIs were technically prepared, so lectures and seminars were held by using Google Classroom service, preparation and presentation of projects were carried out through Internet platforms, information resources, and social networks (Moodle, Zoom, Skype, Viber, Telegram, Messenger, etc.). Also, in the form of additional material, the teachers were introduced to the use of such external online learning systems as the Prometheus platform.

In addition to technical problems, it is also worth noting certain psychological ones faced by both students and teachers. For students, it is the lack of live communication, increased load of tasks, lack of time to complete assignments, control and care for younger family members due to the closure of institutions of preschool and school education, limited access to a computer (because parents and other family members were also transferred to remote work). For teachers, difficulties arose due to the impossibility of individual students counseling, increased time to communicate with them, as online discipline courses involve a more detailed explanation of homework.

Among the positive aspects of HEIs faculty and students' use of online learning (according to the survey results), it was emphasized that the quality of distance learning does not lag behind that of in-person instruction. Students noted the self-organization, allowing education at a convenient place and time, equal and full access to courses, regardless of health, residence, and social status.

Teachers began to play a new role - a mentor, an advisor, coordinating the learning process and constantly improving their skills. During quarantine, a significant number of business schools forged relationships with institutions of higher education and for-profit entities, which, in turn, facilitated both research and advising opportunities for faculty and students.

There was also significant pressure from COVID-19 by HEIs academic staff, as the coronavirus necessitated a rapid transformation of teaching and assessment practices in today's universities (Diachenko et al., 2021; Mufidah et al., 2021). This condition has led to an increase in the workload of academics to peer teams, for example, for software training and collaborative practice activities. Some HEIs were successfully practicing distance education methodology even before the pandemic, but the main share of them carried out their activities only in full-time or part-time form. As a result of the active introduction of distance learning into the educational process, HEIs were faced with the following problems:

- Increasing the technical support level for the full and quality educational process provided in the conditions of distance form of education;

- The need to update the software;

- Improvement of methodological complex adapted to the technology of teaching disciplines in the distance education process;

- The necessity to adjust the load allocated to the study of humanities disciplines;

- Increasing the level of control over the educational process to ensure an appropriate level of professional training, improving procedures for teachers' evaluation of the results of the educational process.

Under the growing pressure of the external environment, HEIs management can be ensured through a wellfunctioning quality management system in higher education (Wahab \& Tyasari, 2020). For example, according to the report on the Kyiv National University named after Shevchenko in 2020-2021, the institution permanently has the Academic Council for the educational process organization. The University Strategic Development Plan for 2018-2025 has been approved per the provisions of the Law of Ukraine "On Higher Education". It ensures the continuous implementation of measures to strengthen the competitive position through the creation of different subsystems, elimination or reorganization of insufficiently effective subsystems, optimization of different subsystems. During 2020-2021, there were created the Center of Digital Competence; Interdisciplinary Analytical Center of Socio-Economic Wellbeing and Mental Health (by the grant from the Renaissance Foundation); Center of Baltic Studies of Institute of Philology; Center of Croatian 
Language and Culture of Philology Institute named after Taras Shevchenko (Kyiv National University) and other structures (official site of Kyiv National University named after Taras Shevchenko, 2021).

The Charter of Kyiv National University named after Taras Shevchenko defines the concept of educational activity: "The main objective of educational activity is to train highly qualified and competitive at both national and international labor market specialists for organizations of all forms of ownership... at all levels of higher education... in all areas of education... an affirmation of national, cultural and human values". This concept defines the functioning of other levels of HEIs' quality management (Table 1). For example, the educational programs' content is subject to a certain university's main objective. In addition to world-class professional training, HEIs should provide students with key competencies for further employment, selfimprovement, active citizenship, and social harmony.

Table 1

The main components of the HEIs management system

\begin{tabular}{|c|c|c|}
\hline $\begin{array}{l}\text { Level of quality } \\
\text { management in higher } \\
\text { education }\end{array}$ & $\begin{array}{l}\text { Kyiv National University named after Taras } \\
\text { Shevchenko }\end{array}$ & National University "Lviv Polytechnic" \\
\hline \multicolumn{3}{|l|}{ Organizational } \\
\hline $\begin{array}{l}\text { Program level (study } \\
\text { programs offered by } \\
\text { HEIs) }\end{array}$ & \multicolumn{2}{|c|}{$\begin{array}{l}\text { HEIs develop and implement educational programs within the received licenses, endowed with } \\
\text { autonomous rights to determine the forms of education. The development and approval of } \\
\text { educational programs are per the International Standard Classification of Higher Education. }\end{array}$} \\
\hline $\begin{array}{l}\text { Unit level (a faculty, a } \\
\text { department, or other } \\
\text { HEI basic unit) }\end{array}$ & \multicolumn{2}{|c|}{$\begin{array}{l}\text { Autonomous and centralized creation, reorganization, and liquidation of structural subdivisions } \\
\text { per development strategies and action plan to strengthen competitiveness. }\end{array}$} \\
\hline \multirow[t]{2}{*}{$\begin{array}{l}\text { Institutional level (the } \\
\text { organizational structure } \\
\text { of HEIs) }\end{array}$} & $\begin{array}{l}\text { HEI is introduced in the market as a classical } \\
\text { university, researching a scientific and } \\
\text { educational center }\end{array}$ & $\begin{array}{l}\text { HEI is introduced in the market as an } \\
\text { educational and research Ukraine center }\end{array}$ \\
\hline & $\begin{array}{l}8 \text { educational institutes, } 13 \text { faculties, } \\
\text { educational-scientific institute, and } \\
\text { educational-scientific center, two colleges, } \\
\text { preparatory department, Ukrainian Physics, } \\
\text { and Mathematics Lyceum, information and } \\
\text { computing center, the center of Ukrainian } \\
\text { studies, museum of university history, } \\
\text { geological and zoological museums, } \\
\text { interfaculty linguistic museum, astronomical } \\
\text { observatory, publishing, and printing center } \\
\text { and scientific library. }\end{array}$ & $\begin{array}{l}10 \text { colleges, } 101 \text { departments, } 16 \text { educational } \\
\text { and scientific institutes, International Institute } \\
\text { of Education, Culture and Diaspora Relations, } \\
\text { Institute of Distance Learning, Scientific and } \\
\text { Technical Library, Research Department, } \\
\text { Publishing House, People's House "Education", } \\
\text { student design and engineering Polytechnic } \\
\text { Association, } 4 \text { training and health camps, an } \\
\text { innovative environment for the } \\
\text { implementation of creative ideas and } \\
\text { successful startups Tech StartUp School, SID } \\
\text { CITY Science Park. }\end{array}$ \\
\hline \multicolumn{3}{|l|}{ Procedural } \\
\hline Teaching and learning & $\begin{array}{l}\text { Periodic improvement of HEI through } \\
\text { educational programs, their revision per the } \\
\text { needs of the labor market, the introduction of } \\
\text { innovative teaching methods through } \\
\text { cooperation with HEIs around the world. }\end{array}$ & $\begin{array}{l}\text { Improving teaching and learning is due to } \\
\text { staff, attracting professionals from various } \\
\text { fields of activity, business to transfer new } \\
\text { knowledge, information, and experience to } \\
\text { specialists. }\end{array}$ \\
\hline $\begin{array}{l}\text { Research and } \\
\text { scholarship }\end{array}$ & $\begin{array}{l}\text { Joint activities with international and domestic } \\
\text { educational institutions and other legal } \\
\text { entities. }\end{array}$ & $\begin{array}{l}\text { International cooperation with universities in } \\
\text { Canada, USA, Germany, France, Great Britain, } \\
\text { Austria, Poland, Slovakia, and other countries. }\end{array}$ \\
\hline Third mission & $\begin{array}{l}\text { Involvement of employers' representatives in } \\
\text { the formation of the content of educational } \\
\text { programs, in the definition of evaluation } \\
\text { procedures, in participation in the educational } \\
\text { process, and final certification. Integration } \\
\text { with enterprises by creating training, research, } \\
\text { and production complexes. }\end{array}$ & $\begin{array}{l}\text { With the support of the private sector, more } \\
\text { than } 30 \text { training and research centers and } \\
\text { laboratories have been opened, including with } \\
\text { the support of Lviv IT Cluster, Roshen, IT } \\
\text { companies GlobalLogic, Eleks, SoftServe, Sigma } \\
\text { Software, PLVision LLC, Intellias, Perfectial, } \\
\text { Conscensia, and Vakoms. AMC Bridge, Leoni } \\
\text { Holding; Siemens Medicine Ltd., etc. }\end{array}$ \\
\hline
\end{tabular}

Kanishevska, L., Shakhrai, V., Aleikseieiva, S., Poyasyk, O., \& Tolochko, S. (2022). Management of HEIs during pandemic. International Journal of Health Sciences, 6(1), 92-102. https://doi.org/10.53730/ijhs.v6n1.3311 


\begin{tabular}{|l|l|l|}
\hline Support processes & $\begin{array}{l}\text { There are several support departments: accounting, academic mobility department, internal } \\
\text { control, and audit department, targeted training department, international cooperation } \\
\text { department, and others. }\end{array}$ \\
\hline \multicolumn{2}{|c|}{ Principles of HEIs' quality management and activities } \\
\hline $\begin{array}{l}\text { Compliance with TQM } \\
\text { principles (+/-) }\end{array}$ & $\begin{array}{l}\text { Do not meet. } \\
\text { Continuity of processes, high guaranteed } \\
\text { quality of education, building educational } \\
\text { programs on a competency basis, establishing } \\
\text { the responsibility of all participants in the } \\
\text { learning process and others. }\end{array}$ & $\begin{array}{l}\text { High professionalism, institutional autonomy, } \\
\text { academic freedom, innovation in research, } \\
\text { trust, teaching, respect, justice. }\end{array}$ \\
\hline
\end{tabular}

Source: author's elaboration based on the Official website of the Kyiv National University named after Taras Shevchenko (2021b); Official website of the National University "Lviv Polytechnic" (2021a; 2021c; 2021d).

The main principles of HEIs functioning in Ukraine differ from the common implementation of TQM principles (customer focus, involvement of people, leadership, process and system approaches, and continual improvement). The Charter of the Kyiv National University named after Taras Shevchenko defines the following principles of functioning:

- The inseparability of the education, research, and production processes;

- High guaranteed quality of education to ensure competitiveness in the national and international market of educational services; construction of educational programs on the competence basis concerning professional standards, labor market needs, and prospects of the industry;

- Recognition of the quality of practical training of the students in the education and research field.

The Charter of the National University "Lviv Polytechnic" defines the following principles of activity:

- Autonomy and self-government;

- Separation of rights, authority, and responsibility of the Ministry of Education and Ukraine, governing bodies of the University and its structural subdivisions

- Combination of collegial and one-man principles;

- Independence from political parties, public and religious organizations.

This discrepancy is explained by the fact that HEIs develop and implement a national quality assurance system in higher education based on monitoring trends in the global educational and scientific space (Van Dinther et al., 2011; Graham et al., 2013). At the same time, to improve the competitiveness of human resources, HEIs research the modern labor market in Ukraine and carry out marketing support of educational services, monitoring the status of employment and graduates' career development.

\subsection{Discussions}

During the spread of coronavirus disease, the management systems of HEIs of Ukraine were negatively affected by internal and external factors that existed before the pandemic and were exacerbated during its spread:

- Internal: irrational use of available financial resources and inability to attract them from external sources; inefficient personnel structure and motivation system of TEP (teaching and education process) work in HEIs system; ineffective management; inconsistency of specialties and educational programs with market conditions; reduction of the level of training of HEIs graduates, inconsistency of their knowledge with modern needs of the labor market; lack of experience in the interaction of HEIs with stakeholders; low level of informatization and lack of resources for digitalization of the educational process, the unpreparedness of some HEIs for the introduction of distance learning (Ali, 2020; Arora \& Srinivasan, 2020; Bao, 2020);

- External: impact on the development of the educational sphere of the COVID-19 pandemic and the need to adapt HEIs and higher education management systems to new living conditions; competition in the 
external and internal market of educational services; change in the structure of the economy and the consequent reduction in the need for specialists with higher education in various fields; low level of solvency of the population; demographic situation and decrease of entrants' potential number; outflow of highly qualified teachers and scientists abroad; underfunding of HEIs and, as a result, reducing its attractiveness to highly qualified personnel; investment climate and investment resources; inefficient system of management and regulation of HE; tariffs for energy resources, utilities) (Cicha et al., 2021; Mishra et al., 2020; Paudel, 2021; Ramírez-Hurtado et al., 2021).

At the same time, it should be noted that there are some opportunities for the development of the management system of HEIs, including change in Ukraine's public policy in the field of education; labor market conditions in the context of the supply of scientific and pedagogical staff and the demand for specialists in certain specialties; licensing and accreditation system; system of training, retraining and advanced training of scientific personnel. The spread of the pandemic posed new important challenges to the entire world community, the solution of which highlighted the need for digitalization processes in all spheres of life, including in higher education institutions (Meissner et al., 2018; Gjellebæk et al., 2020). So, today universities' transforming tasks into institutions of the latest type: digital universities and networks of universities without borders (borderless networks of universities). To successfully solve this issue, it is necessary to increase the level of understanding of the problem and the ability of educational institutions to implement projects, the ability to apply and develop the information environment of educational institutions, the degree of digital competence of all participants in the educational process.

\section{Conclusion}

In general, the pandemic has generated significant structural changes in the HEIs management system, driven by changing student needs, the development and diffusion of innovative learning technologies, the reduction of international students, the closure, mergers, and restructuring of universities through reduced funding. The pandemic has challenged the core activities of higher education institutions to support students through a wide range of curricula. It significantly complicates the implementation of interactive, personality-oriented traditional classroom learning, based on many years of universities' experience. To adapt to a long-term pandemic, HEIs need flexible methods of education to continuously adapt to different transformational stages. COVID-19 has led to the intensification of long-term teaching trends; created a natural experiment, which allows to test and evaluate numerous innovations. The first results already indicate that a large number of innovations that were applied during the pandemic will be used for students after the crisis.

Acknowledgments

We are grateful to two anonymous reviewers for their valuable comments on the earlier version of this paper.

Kanishevska, L., Shakhrai, V., Aleikseieiva, S., Poyasyk, O., \& Tolochko, S. (2022). Management of HEIs during pandemic. International Journal of Health Sciences, 6(1), 92-102. https://doi.org/10.53730/ijhs.v6n1.3311 


\section{References}

Ali, W. (2020). Online and remote learning in higher education institutes: A necessity in light of COVID-19 pandemic. Higher education studies, 10(3), 16-25.

Antonopoulou, H., Halkiopoulos, C., Barlou, O., \& Beligiannis, G. N. (2021). Transformational leadership and digital skills in higher education institutes: during the COVID-19 pandemic. Emerging science journal, 5(1), $1-15$.

Arora, A. K., \& Srinivasan, R. (2020). Impact of pandemic COVID-19 on the teaching-learning process: A study of higher education teachers. Prabandhan: Indian journal of management, 13(4), 43-56.

Arshad, M., Almufarreh, A., Noaman, K. M., \& Saeed, M. N. (2020). Academic Semester Activities by Learning Management System during COVID-19 Pandemic: A Case of Jazan University. International Journal on Emerging Technologies, 11(5), 213-219.

Attamimi, H. R. ., Lestari, Y. ., Situmorang, B. . H. L. ., Antari, G. Y. ., \& Nugrawati, N. (2020). Application of habituation method in germas interventionsin: the pandemic time COVID-19. International Journal of Health \& Medical Sciences, 3(1), 98-104.

Bao, W. (2020). COVID-19 and online teaching in higher education: A case study of Peking University. Human Behavior and Emerging Technologies, 2(2), 113-115.

Blankenberger, B., \& Williams, A. M. (2020). COVID and the impact on higher education: The essential role of integrity and accountability. Administrative Theory \& Praxis, 42(3), 404-423.

Cicha, K., Rizun, M., Rutecka, P., \& Strzelecki, A. (2021). COVID-19 and higher education: first-year students' expectations toward distance learning. Sustainability, 13(4), 1889.

Diachenko, A., Vusyk, H., Bielova, Y., Shurdenko, M., \& Titenko, O. (2021). The educational role in COVID-19 terms of ethnodesign graphic function in higher education practical activities. International Journal of Health Sciences, 5(3), 584-593. https://doi.org/10.53730/ijhs.v5n3.2540

García-Morales, V. J., Garrido-Moreno, A., \& Martín-Rojas, R. (2021). The transformation of higher education after the COVID disruption: Emerging challenges in an online learning scenario. Frontiers in Psychology, 12, 196.

Garrison, D. R., \& Kanuka, H. (2004). Blended learning: Uncovering its transformative potential in higher education. The internet and higher education, 7(2), 95-105. https://doi.org/10.1016/j.iheduc.2004.02.001

Gjellebæk, C., Svensson, A., Bjørkquist, C., Fladeby, N., \& Grundén, K. (2020). Management challenges for future digitalization of healthcare services. Futures, 124, 102636. https://doi.org/10.1016/j.futures.2020.102636

Graham, C. R., Woodfield, W., \& Harrison, J. B. (2013). A framework for institutional adoption and implementation of blended learning in higher education. The internet and higher education, 18, 4-14. https://doi.org/10.1016/j.iheduc.2012.09.003

Jouault, F., Allilaire, F., Bézivin, J., \& Kurtev, I. (2008). ATL: A model transformation tool. Science of computer programming, 72(1-2), 31-39. https://doi.org/10.1016/j.scico.2007.08.002

Kaur, M. (2013). Blended learning-its challenges and future. Procedia-social and behavioral sciences, 93, 612617. https://doi.org/10.1016/j.sbspro.2013.09.248

Lytvyn, V., Akimova, O., Kuznetsova, H., Zenchenko, T., Stepanenko, O., \& Koreneva, I. (2021). The use of synchronous and asynchronous teaching methods in pedagogical education in COVID-19 terms. International Journal of Health Sciences, 5(3), 617-629. https://doi.org/10.53730/ijhs.v5n3.2681

Manatos, M. J., Sarrico, C. S., \& Rosa, M. J. (2017). The integration of quality management in higher education institutions: a systematic literature review. Total Quality Management \& Business Excellence, 28(1-2), 159175.

Markova, T., Glazkova, I., \& Zaborova, E. (2017). Quality issues of online distance learning. Procedia-Social and Behavioral Sciences, 237, 685-691. https://doi.org/10.1016/j.sbspro.2017.02.043

Meissner, A., Müller, M., Hermann, A., \& Metternich, J. (2018). Digitalization as a catalyst for lean production: A learning factory approach for digital shop floor management. Procedia manufacturing, 23, 81-86. https://doi.org/10.1016/j.promfg.2018.03.165

Melo, A. I., Sarrico, C. S., \& Radnor, Z. (2010). The influence of performance management systems on key actors in universities: the case of an English university. Public Management Review, 12(2), 233-254.

Mishra, L., Gupta, T., \& Shree, A. (2020). Online teaching-learning in higher education during lockdown period of COVID-19 pandemic. International Journal of Educational Research Open, 1, 100012. https://doi.org/10.1016/j.ijedro.2020.100012 
Moore, J. L., Dickson-Deane, C., \& Galyen, K. (2011). e-Learning, online learning, and distance learning environments: Are they the same?. The Internet and higher education,14(2), 129-135. https://doi.org/10.1016/j.iheduc.2010.10.001

Mufidah, N., Suhron, M., \& Wahyudi, R. (2021). Analysis of post-stroke anxiety (PSA) factors during the COVID19 pandemic in Indonesia. International Journal of Health \& Medical Sciences, 5(1), 1-6. https://doi.org/10.21744/ijhms.v5n1.1807

Paudel, P. (2021). Online education: Benefits, challenges and strategies during and after COVID-19 in higher education. International Journal on Studies in Education, 3(2), 70-85.

Ramírez-Hurtado, J. M., Hernández-Díaz, A. G., López-Sánchez, A. D., \& Pérez-León, V. E. (2021). Measuring Online Teaching Service Quality in Higher Education in the COVID-19 Environment. International Journal of Environmental Research and Public Health, 18(5), 2403.

Shahzad, A., Hassan, R., Aremu, A. Y., Hussain, A., \& Lodhi, R. N. (2021). Effects of COVID-19 in E-learning on higher education institution students: the group comparison between male and female. Quality \& quantity, 55(3), 805-826.

Stensaker, B., Langfeldt, L., Harvey, L., Huisman, J., \& Westerheijden, D. (2011). An in-depth study on the impact of external quality assurance. Assessment \& Evaluation in Higher Education, 36(4), 465-478.

Toquero, C. M. (2020). Challenges and opportunities for higher education amid the COVID-19 pandemic: The Philippine context. Pedagogical Research, 5(4).

Van Dinther, M., Dochy, F., \& Segers, M. (2011). Factors affecting students' self-efficacy in higher education. Educational research review, 6(2), 95-108. https://doi.org/10.1016/j.edurev.2010.10.003

van Vught, F., \& Westerheijden, D. F. (2010). Multidimensional ranking: a new transparency tool for higher education and research. Higher Education Management and Policy, 22(3), 1-26.

Wahab, A., \& Tyasari, I. (2020). Entrepreneurial leadership for university leaders: A futuristic approach for Pakistani HEIs. Asia Pacific Management Review, 25(1), 54-63. https://doi.org/10.1016/j.apmrv.2019.09.002

Widana, I.K., Sumetri, N.W., Sutapa, I.K., Suryasa, W. (2021). Anthropometric measures for better cardiovascular and musculoskeletal health. Computer Applications in Engineering Education, 29(3), 550561. https://doi.org/10.1002/cae.22202

Kanishevska, L., Shakhrai, V., Aleikseieiva, S., Poyasyk, O., \& Tolochko, S. (2022). Management of HEIs during pandemic. International Journal of Health Sciences, 6(1), 92-102. https://doi.org/10.53730/ijhs.v6n1.3311 


\section{Biography of Authors}

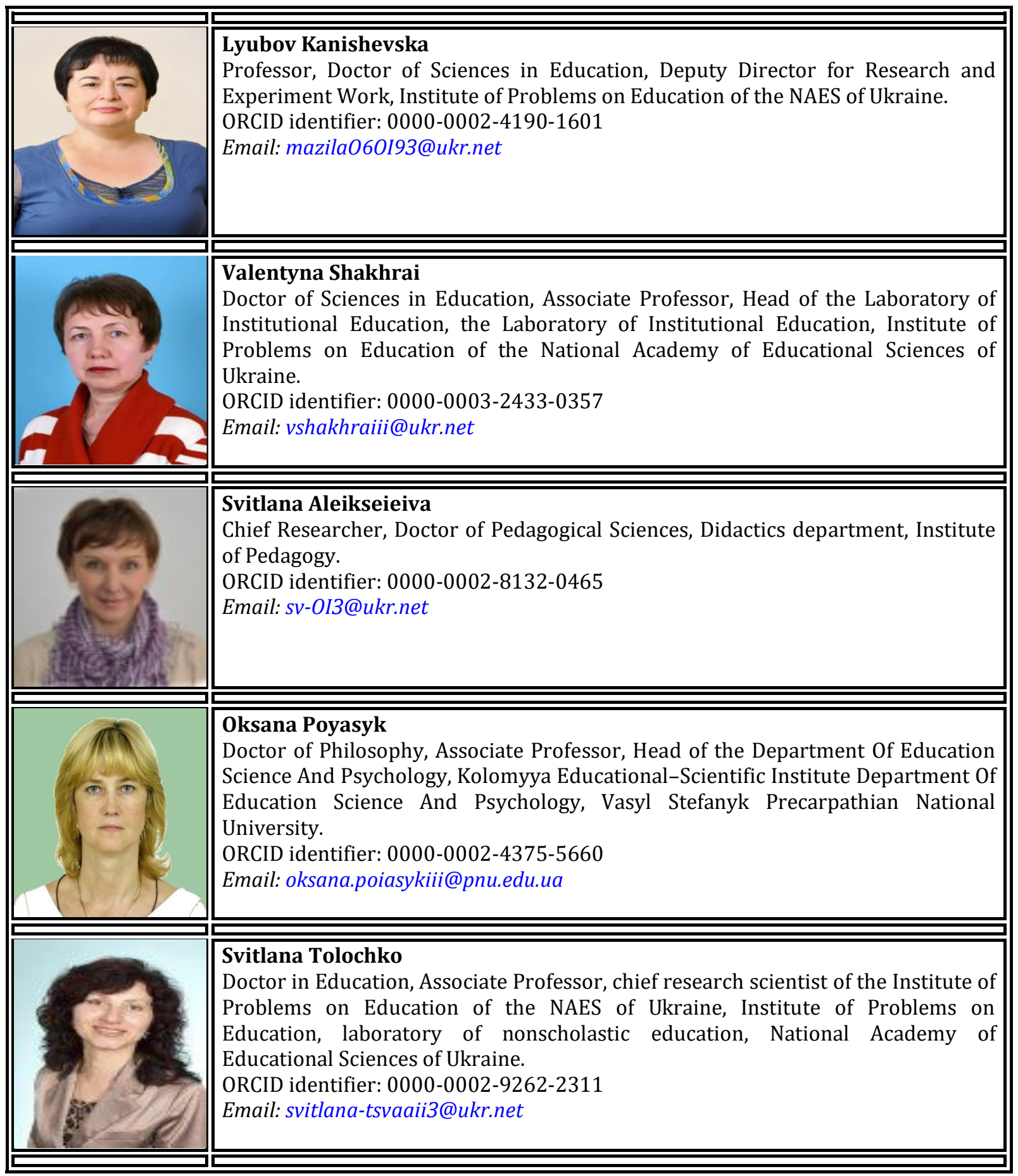

